\title{
ANALYSIS OF CORRELATION BETWEEN CEREBROSPINAL FLUID AND PLASMA HIV-1 RNA LEVELS IN PATIENTS WITH NEUROLOGICAL OPPORTUNISTIC DISEASES
}

\author{
Paulo Pereira CHRISTO(1), Dirceu Bartolomeu GRECO(3), Agdemir Waleria ALEIXO(3) \& Jose António LIVRAMENTO(2)
}

\begin{abstract}
SUMMARY
The question of whether HIV-1 RNA in cerebrospinal fluid (CSF) is derived from viral replication in the central nervous system or simply reflects the transit of infected lymphocytes from the blood compartment has long been a matter of debate. Some studies found no correlation between CSF and plasma viral load, whereas others did. The lack of a correlation between the two compartments suggests that the presence of HIV-1 RNA is not simply due to the passive passage of the virus from blood to CSF but rather due to intrathecal replication. To evaluate the correlation between plasma and CSF HIV-1 RNA levels and to identify situations in which there is no correlation between the two compartments, seventy patients were prospectively studied. The association between CSF and plasma viral load was evaluated in the total population and in subgroups of patients with similar characteristics. A correlation between the CSF and plasma compartments was observed for patients undergoing highly active antiretroviral therapy (HAART), those with a CD4 T lymphocyte count lower than 200 cells $/ \mathrm{mm}^{3}$, and those with increased CSF protein content. On the other hand, no correlation was observed for patients without adequate virological control, who had a CD4 count higher than 200 cells $/ \mathrm{mm}^{3}$ and who did not use HAART. The correlation between the two compartments observed in some patients suggests that CSF HIV-1 RNA levels may reflect plasma levels in these subjects. In contrast, the lack of a correlation between the two compartments in patients who were not on HAART and who had normal CSF proteins and a poor virological control possibly indicates compartmentalization of the virus in CSF and, consequently, plasma-independent intrathecal viral replication.
\end{abstract}

KEYWORDS: AIDS; HIV; Cerebrospinal fluid; HIV-1 RNA; Opportunistic infections; Viral load; Neurological.

\section{INTRODUCTION}

Plasma HIV-1 RNA levels indicate the status of systemic viral replication and represent the best predictive marker of HIV-1 disease progression (MELLORS 1995) and the most important tool for monitoring the response to antiretroviral (ARV) therapy (PIATAK et al. 1993, PERELSON et al. 1996, MELLORS et al. 1997). Quantitative amplification techniques of HIV-1 RNA in different body fluids, including cerebrospinal fluid (CSF), have been applied to HIV-infected adults and children but, in contrast to plasma HIV levels, their predictive value has not been well established (McARTHUR et al. 2003, MARRA et al. 2003).

Quantitative studies generally show higher mean and median HIV1 RNA levels in plasma than in CSF, but higher CSF levels have been reported in certain cases (CINQUE et al. 2000, DE LUCA et al. 2002, LAFEUILLADE et al. 1996, BURGER et al. 1997). Some investigators found no correlation between CSF and plasma viral load (BREW et al. 1997, ELLIS et al. 1997, CINQUE et al. 1998, MARTIN et al. 1998, FOUDRAINE et al. 1998, SCHRAGER et al. 1998, ANTINORI et al. 2002), while others did (McARTHUR et al. 1997, BOSSI et al. 1998, ROBERTSON et al. 1998, GARCIA et al. 1999). The lack of a correlation between the two compartments suggests that the presence of HIV-1 RNA may not simply be due to passive passage of the virus from blood to CSF but rather to intrathecal replication (CINQUE et al. 1998, SMITH et al. 2009).

The question of whether HIV-1 RNA in cerebrospinal fluid (CSF) is derived from viral replication in the central nervous system or simply reflects the transit of infected lymphocytes from the blood compartment has long been a matter of debate. This is important because it involves the validity of the measurement of HIV RNA levels in CSF as a replacement of brain viral load (CINQUE et al. 2000). The objective of the present study was to evaluate the correlation between plasma and CSF HIV-1 RNA levels in individuals with a suspicion of opportunistic neurological disease and to identify situations in which there is no correlation between the two compartments.

\section{MATERIALS AND METHODS}

Seventy patients undergoing lumbar puncture as part of a work-up for HIV seropositive individuals with a suspicion of neurological disease hospitalized at a referral hospital for infectology in the State of Minas Gerais, Brazil, were prospectively studied. The study was approved by

(1) Department of Neurology and Post-graduate of Santa Casa de Belo Horizonte, Eduardo de Menezes Hospital, FHEMIG, Belo Horizonte, MG, Brazil.

(2) Department of Neurology, University of São Paulo, São Paulo, SP, Brazil.

(3) Department of Infectious Diseases, Federal University of Minas Gerais, Belo Horizonte, MG, Brazil.

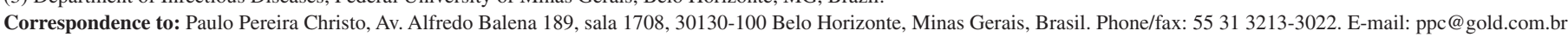


CHRISTO, P.P.; GRECO, D.B.; ALEIXO, A.W. \& LIVRAMENTO, J.A. - Analysis of correlation between cerebrospinal fluid and plasma HIV-1 RNA levels in patients with neurological opportunistic diseases. Rev. Inst. Med. Trop. Sao Paulo, 53(4): 193-6, 2011.

the Ethics Committee of the Hospital and consent was obtained from all participants.

In the case of patients without neurological diseases the clinical diagnoses were primary headache, metabolic/toxic disorders, and fever with a non-neurological focus.

Clinical and laboratory data including gender, age, use or not of combination antiretroviral therapy (ART), presence and type of neurological disease, CD4+ T lymphocyte count, and CSF cell count and protein content were collected.

CSF and plasma samples were collected within an interval of 48 hours between each other. HIV-1 RNA was quantified by the nucleic acid sequence based amplification (NASBA) technique using centrifuged plasma and not centrifuged CSF according to manufacturer instructions (Nuclisens HIV-1 QT, Organon TeKniKa, Boxtel, Netherlands), with a sensitivity of 80 copies/mL ( $1.90 \log _{10}$ copies $\left./ \mathrm{mL}\right)$.

The association between viral load in the CSF and plasma compartments was evaluated using Spearman's correlation coefficient. To evaluate the existence of statistically significant difference between frequencies, Chi-square test was used. P values $<0.05$ were considered to indicate statistical significance. CSF and plasma viral loads were $\log _{10}$ transformed since the HIV-1 RNA levels showed no normal distribution and there is big variation of the minimum and maximum viral load. Patients with undetectable viral load were assigned a value of 1 , so the viral load in the logarithmic scale was 0 to avoid the problem of expressing zero logarithmically. All statistical analyses were performed with the SPSS 8.0 program (SPSS Inc.).

\section{RESULTS}

Characteristics of the study population are summarized in Table 1. Twelve of the 70 patients studied were without neurological disease and 58 had active neurological diseases. The median CD4+ lymphocyte count was 83 cells $/ \mathrm{mm}^{3}$ in the population studied, with the median count being 61 cells $/ \mathrm{mm}^{3}$ in patients without neurological disease and 88 cells $/ \mathrm{mm}^{3}$ in patients with active neurological diseases. Twelve patients had a CD4+ count higher than 200 cells $/ \mathrm{mm}^{3}$. No differences in median CD4+ lymphocyte count were observed between patients with and without active neurological disease or between patients who used HAART and those who did not.

The median cell count was 5 cells $/ \mathrm{mm}^{3}$ and the median protein concentration was $61 \mathrm{mg} / \mathrm{dL}$. The CSF protein content was higher than $45 \mathrm{mg} / \mathrm{dL}$ in 44 (63\%) patients and the number of CSF cells was higher than 5 cells $/ \mathrm{mm}^{3}$ in $35(50 \%)$ patients. The median cell count was 8 cells $/ \mathrm{mm}^{3}$ in patients with active neurological disease and 2 cells $/ \mathrm{mm}^{3}$ in those without neurological disease $(p<0.0001)$; median protein content was 63 and $38 \mathrm{mg} / \mathrm{dL}$, respectively $(p=0.084)$.

Among the 70 patients studied, HIV-1 RNA was detected in 42 CSF samples and in 56 plasma samples (detection limit: 80 copies $/ \mathrm{mL}$ ), with viral RNA greater than the detection limit being detected in the two compartments in 40 patients. Among 35 patients using HAART, HIV RNA was detected in CSF in 14 patients, in plasma in 22, and in 18 patients at both compartments.
Table 1

Characteristics of the 70 subjects studied

\begin{tabular}{|c|c|}
\hline Mean age [years (interquartile range)] & $37(20-60)$ \\
\hline \multicolumn{2}{|l|}{$\operatorname{Sex}(n)$ : } \\
\hline Male & 50 \\
\hline Female & 20 \\
\hline \multicolumn{2}{|l|}{ CD4-positive cells (cells $/ \mathrm{mm}^{3}$ ): } \\
\hline Mean & 142 \\
\hline Median & 83 \\
\hline Range & $1-405$ \\
\hline Pre-existing ARV therapy (n): & 12 \\
\hline Yes & 35 \\
\hline No & 35 \\
\hline $\begin{array}{l}\text { Mean duration of ARV therapy [months (interquar- } \\
\text { tile range)] }\end{array}$ & $10.4(0.5-60)$ \\
\hline Neurologically asymptomatic (n) & 12 \\
\hline Neurologically symptomatic (n): & 58 \\
\hline HIV-associated dementia & 5 \\
\hline Vacuolar myelopathy & 1 \\
\hline \multicolumn{2}{|l|}{ Opportunistic CNS infections: } \\
\hline Toxoplasmosis & 16 \\
\hline Cryptococcal meningitis & 12 \\
\hline Tuberculosis meningitis & 3 \\
\hline PML & 1 \\
\hline \multicolumn{2}{|l|}{ Opportunistic CNS infections associations: } \\
\hline Cryptococcal and tuberculous & 2 \\
\hline Cryptococcal and toxoplasmosis & 1 \\
\hline Cryptococcal and vacuolar myelopathy & 1 \\
\hline Other (stroke, brain abscess, neuropathy) & 3 \\
\hline Undetermined neurological diagnosis & 13 \\
\hline
\end{tabular}

ARV: antiretroviral drug; CNS: central nervous system; PML: progressive multifocal leukoencephalopathy.

The median CSF viral load was $2.81 \log _{10}$ copies/mL in the total population, $3.27 \log _{10}$ copies $/ \mathrm{mL}$ in patients with active neurological disease, and $<1.9 \log _{10}$ copies $/ \mathrm{mL}$ in patients without neurological disease $(p<001)$. The median plasma viral load was $4.28,4.35$ and $2.45 \log _{10}$ copies/mL, respectively $(p<001)$. The median CSF and plasma viral loads were $<1.9$ and $2.69 \log _{10}$ copies/mL in patients undergoing HAART and 3.76 and $5.08 \log _{10}$ copies/mL in those not receiving HAART, respectively. All these results showed statistically significant differences.

Correlation between CSF and plasma viral load: a significant correlation between the two compartments was observed in the total population (70 patients) $(\mathrm{r}=0.543, p<0.001)$. However, no correlation between the two compartments was found when only patients with $\mathrm{CSF}$ and plasma viral loads higher than the detection limit (40 patients) were considered $(r=0.242, p=0.132)$. A correlation between the two compartments continued to be observed when the patients were divided into groups with (58 patients) and without active neurological disease (12 patients) $(\mathrm{r}=0.516, p<0.001$ and $\mathrm{r}=0.633, p=0.027$, respectively).

The patients were also divided according to immunological state, measured by CD4+ lymphocyte count into those with a count higher (12 patients) and lower (58 patients) than 200 cells $/ \mathrm{mm}^{3}$. A correlation between 


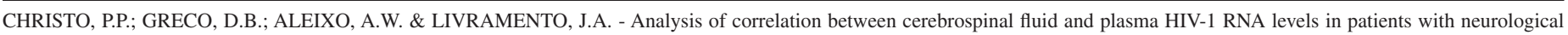
opportunistic diseases. Rev. Inst. Med. Trop. Sao Paulo, 53(4): 193-6, 2011.

the two compartments was observed in patients with a CD4+ count lower than $200 \mathrm{cell} / \mathrm{mm}^{3}(\mathrm{r}=0.507, p<0.001)$ and no correlation was found in patients with a CD4+ count higher than 200 cells $/ \mathrm{mm}^{3}(\mathrm{r}=0.530, p=0.077)$. With respect to the use of HAART, there was a correlation between compartments in the group that used HAART $(\mathrm{r}=0.498, p=0.002)$, and no correlation in the group who did not $(\mathrm{r}=0.250, p=0.148)$.

When dividing the patients according to CSF protein content, a correlation between CSF and plasma viral load was observed in those with increased protein $(\mathrm{r}=0.608, p<0.001)$ and no correlation in those with normal protein content $(\mathrm{r}=0.280, p=0.195)$.

\section{DISCUSSION}

In the present study, a correlation between the CSF and plasma compartments was observed in the total population which, in principle, may indicate that CSF HIV-1 RNA levels reflect plasma levels. However, the separate calculation of correlation in groups of patients with common characteristics revealed the absence of a correlation in certain situations, a finding suggesting the occurrence of HIV-1 compartmentalization in CSF in some patients.

No correlation between the two compartments was observed when only patients with a detectable viral load in CSF and plasma, and therefore without virological control, were considered for analysis. Patients with a plasma and CSF viral load lower than the detection limit were those who most frequently used HAART and were responsible for the existence of a correlation on statistical analysis. However, when these patients were excluded from analysis, no correlation between the two compartments was observed in patients not controlled by HAART therapy (viral load > 80 copies/mL), suggesting that the use of ARV drugs is responsible for virological control in plasma and CSF and that compartmentalization of HIV-1 RNA in CSF may have occurred in not well-controlled patients. No correlation between CSF and plasma viral load was observed in patients with higher viral replication in plasma and CSF. This fact was also reported by DE LUCA et al. (2002) who found a correlation between CSF and plasma viral load, but this correlation was no longer observed when only patients with a high CSF $\left(>4.0 \log _{10} / \mathrm{mL}\right)$ and plasma $\left(>5.0 \log _{10} / \mathrm{mL}\right.$ ) viral load were included, and continued to be observed in those with lower CSF and plasma HIV-1 RNA levels.

When the patients were divided into groups with and without active neurological disease, a correlation between the two compartments was observed in both groups, demonstrating that this correlation does not depend on the isolated presence or absence of neurological disease. A correlation between the two compartments has been shown in asymptomatic subjects (GARCIA et al. 1999), while no correlation has been found in patients with more advanced disease, with HIV affecting the central nervous system, or in patients with opportunistic diseases (CINQUE et al. 1998). Opportunistic neurological diseases increase HIV-1 RNA levels in the CSF and plasma, but the increase is more significant in CSF (CHRISTO et al. 2005, CHRISTO et al. 2007, CECCHINI et al. 2009).

There was a correlation in the group of patients with poor immunity (CD4+ count lower than 200 cells $/ \mathrm{mm}^{3}$ ), but not in the group with a CD4+ count higher than 200 cells $/ \mathrm{mm}^{3}$. However, the latter group showed a high correlation coefficient and level of significance close to $95 \%$ $(\mathrm{r}=0.507$ and $p=0.077)$ and consisted of only 12 patients for analysis.
A study evaluating patients with mild cognitive symptoms and dementia reported a correlation between the two compartments only in subjects with a CD4+ count lower than 200 cells $/ \mathrm{mm}^{3}$ (McARTHUR et al. 1997). However, another investigation evaluating patients with minor cognitive disorder and asymptomatic subjects found a correlation only in patients with a CD4+ count higher than 200 cells $/ \mathrm{mm}^{3}$, but none of those patients presented opportunistic diseases or HIV-associated dementia as was the case in the present study. The presence of this correlation in less advanced stages was explained by the authors on the basis of the greater transit of lymphocytes to the CSF during earlier phases of infection (ELLIS et al. 1997). The present study suggests that CD4+ count is not the only factor involved in the correlation between the two compartments.

There was a strong correlation between CSF and plasma viral load in the group with increased CSF protein content, whereas no correlation was observed in patients with normal CSF proteins. Patients with a protein content higher than $45 \mathrm{mg} / \mathrm{dL}$ most frequently had neurological diseases, especially opportunistic diseases, and most frequently presented increased cell counts. This finding suggests breakdown of the bloodbrain barrier which would explain the correlation between the two compartments, with CSF HIV-1 levels reflecting plasma levels, or even that the increase in viral replication in CSF occurs in parallel to the increase in plasma viral load and that HIV proteins and/or opportunistic diseases cause a host reaction generating globulins in CSF. However, the blood-brain barrier was not evaluated in the present study. In contrast, in patients with normal protein content viral load was not correlated, indicating the possible compartmentalization of HIV-1 RNA in CSF.

A correlation was observed in the group under HAART, with these patients showing a lower mean viral load both in plasma and CSF, suggesting that adequate control in one compartment leads to control of infection in the other. In the group not using HAART and without adequate control, no correlation was observed between the two compartments, a finding suggesting the existence of compartmentalization in this case. In the HAART era, ANTINORI et al. (2002) also found a correlation between plasma and CSF viral load only in patients using ARV drugs but not in treatment-naive individuals.

Studies disagree on the correlation between CSF and plasma viral load (BREW et al. 1997, ELLIS et al. 1997, CINQUE et al. 1998, MARTIN et al. 1998, FOUDRAINE et al. 1998, McARTHUR et al. 1997, BOSSI et al. 1998, ROBERTSON et al. 1998). However, as seen in the present study, this may depend on the characteristics of the study population such as stage of HIV disease, presence of neurological disease, use and type of ARV therapy, CSF parameters and, possibly, other factors not investigated.

The present study found a correlation between CSF and plasma viral load in patients on HAART, in those with low immunity and in those with an increased CSF protein content, with CSF HIV-1 RNA levels probably reflecting plasma levels in these cases. These findings also suggest the active transporting of HIV through the blood-brain barrier or synchronized replication of the virus in plasma and brain, possibly mediated by cytokines (BOSSI et al. 1998). In contrast, no correlation between the two compartments was observed in patients who did not use HAART and those with normal CSF proteins and better immunity, indicating a possible compartmentalization of the virus in CSF and, consequently, plasma-independent intrathecal viral replication. 
CHRISTO, P.P.; GRECO, D.B.; ALEIXO, A.W. \& LIVRAMENTO, J.A. - Analysis of correlation between cerebrospinal fluid and plasma HIV-1 RNA levels in patients with neurological opportunistic diseases. Rev. Inst. Med. Trop. Sao Paulo, 53(4): 193-6, 2011.

\section{RESUMO}

\section{Análise da correlação entre os níveis de RNA do HIV-1 no líquido cefalorraquidiano e plasma em pacientes com doença neurológica oportunista}

Tem sido objeto de debate a questão se o RNA do HIV-1 no líquido cefalorraquidiano (LCR) é derivado da replicação viral no sistema nervoso central ou simplesmente reflete o tráfego de linfócitos infectados do compartimento sanguíneo. Alguns estudos não mostraram correlação entre a carga viral do plasma e LCR, mas outros sim. A falta de correlação entre os dois compartimentos sugere que a presença de RNA do HIV-1 não é simplesmente devido à passagem do vírus do plasma para o LCR, mas sim a uma replicação intratecal. Para avaliar a correlação entre os níveis de RNA do HIV-1 no plasma e no LCR e tentar identificar situações, na qual, não existe a correlação entre os dois compartimentos avaliaram-se setenta pacientes prospectivamente. A associação entre a carga viral do LCR e plasma foi avaliada na população total e em subgrupos de pacientes com características similares. A correlação entre os dois compartimentos foi observada em pacientes que estavam em uso da terapia antiretroviral (HAART), naqueles que tinham contagem de linfócitos CD4 menor que 200 céls $/ \mathrm{mm}^{3}$ e naqueles com aumento da concentração de proteínas no LCR. Por outro lado, não houve correlação para os pacientes que não tinham um controle virológico adequado, os que tinham contagem de CD4 maior que 200 céls $/ \mathrm{mm}^{3}$ e aqueles que não estavam usando HAART. A correlação entre os dois compartimentos observada em alguns pacientes sugere que os níveis de RNA do HIV-1 no LCR podem refletir os níveis plasmáticos nestes pacientes. E a falta de correlação ente os dois compartimentos em pacientes que não usavam HAART, nos que tinham uma concentração de proteínas no LCR normal, e nos que não apresentavam bom controle virológico, indica provavelmente a compartimentalização do vírus no LCR e consequentemente replicação viral intratecal independente da do plasma.

\section{REFERENCES}

1. Antinori A, Giancola ML, Grisetti S, Soldani F, Alba L, Liuzzi G, et al. Factors influencing virological response to antiretroviral drugs in cerebrospinal fluid of advanced HIV-1 infected patients. AIDS. 2002;16:1867-76.

2. Bossi P, Dupin N, Coutellier A, Bricaire F, Lubetzki C, Katlama C, et al. The level of human immunodeficiency virus (HIV) type 1 RNA in cerebrospinal fluid as a marker of HIV encephalitis. Clin Infect Dis. 1998;26:1072-3.

3. Brew BJ, Pemberton L, Cunningham P, Law MG. Levels of human immunodeficiency virus type 1 RNA in cerebrospinal fluid correlate with AIDS dementia stage. J Infect Dis. 1997; 175:963-6.

4. Burger DM, Boucher CA, Meenhorst PL, Kraayeveld CL, Portegies P, Mulder JW, et al. HIV-1 RNA levels in the cerebrospinal fluid may increase owing to damage to the blood-brain barrier. Antivir Ther. 1997;2:113-7.

5. Cecchini DM, Cañizal AM, Rojas H, Arechavala A, Negroni R, Bouzas MB, et al. Variables that influence HIV-1 cerebrospinal fluid viral load in cryptococcal meningitis: a linear regression analysis. J Int AIDS Soc. 2009;2:8.

6. Christo PP, Greco DB, Aleixo AW, Livramento JA. HIV-1 RNA levels in cerebrospinal fluid and plasma and their correlation with opportunistic neurological diseases in a Brazilian AIDS reference Hospital. Arq Neuropsiquiatr. 2005;63:907-13.

7. Christo PP, Greco DB, Aleixo AW, Livramento JA. Factors influencing cerebrospinal fluid and plasma HIV-1 RNA detection rate in patients with and without opportunistic neurological disease during the HAART era. BMC Infect Dis. 2007;7:147.
8. Cinque P, Bestetti A, Moreli P, Presti S. Molecular analysis of cerebrospinal fluid: potential for the study of HIV-1 infection of central nervous system. J Neurovirol. 2000;6(Suppl 1):S95-S102.

9. Cinque P, Vago L, Ceresa D, Mainini F, Terreni MR, Vagani A, et al. Cerebrospinal fluid HIV-1 RNA levels: correlation with HIV encephalitis. AIDS. 1998;12:389-94.

10. De Luca A, Ciancio BC, Larussa D, Murri R, Cingolani A, Rizzo MG, et al. Correlates of independent HIV-1 replication in the CNS and of its control by antiretrovirals. Neurology. 2002;59:342-7.

11. Ellis RJ, Hsia K, Spector SA, Nelson JA, Heaton RK, Wallace MR, et al. Cerebrospinal fluid human immunodeficiency virus type 1 RNA levels are elevated in neurocognitively impaired individuals with acquired immunodeficiency syndrome. HIV Neurobehavioral Research Center Group. Ann Neurol. 1997;42:679-88.

12. Foudraine NA, Hoetelmans RM, Lange JM, de Wolf F, van Benthem BH, Maas JJ, et al.. Cerebrospinal fluid HIV-1 RNA and drug concentrations after treatment with lamivudine plus zidovudine or stavudine. Lancet, 1998;351:1547-51.

13. Garcia F, Niebla G, Romeu J, Vidal C, Plana M, Ortega M, et al. Cerebrospinal fluid HIV-1 RNA levels in asymptomatic patients with early stage chronic HIV-1 infection: support for the hypothesis of local virus replication. AIDS. 1999;13:1491-6.

14. Lafeuillade A, Poggi C, Pellegrino P, Corti K, Profizi N, Sayada C. HIV-1 replication in the plasma and cerebrospinal fluid. Infection. 1996;24:367-71.

15. Marra CM, Lockhart D, Zunt JR, Perrin M, Coombs RW, Collier AC. Changes in CSF and plasma HIV-1 RNA and cognition after starting potent antiretroviral therapy. Neurology. 2003;60:1388-90.

16. Martin C, Albert J, Hansson P, Pehrsson P, Link H, Sonnerborg A. Cerebrospinal fluid mononuclear cell counts influence CSF HIV-1 RNA levels. J Acquir Immune Defic Syndr Hum Retrovirol. 1998;17:214-9.

17. McArthur JC, Haughey N, Gartner S, Conant K, Pardo C, Nath A, et al.. Human immunodeficiency virus-associated dementia: an evolving disease. J Neurovirol. 2003;9:205-21.

18. McArthur JC, McClernon DR, Cronin MF, Nance-Sproson TE, Saah AJ, St Clair M, et al. Relationship between human immunodeficiency virus-associated dementia and viral load in cerebrospinal fluid and brain. Ann Neurol. 1997;42:689-98.

19. Mellors JW, Kingsley LA, Rinaldo CR Jr, Todd JA, Hoo BS, Kokka RP, et al. Quantitation of HIV-1 RNA in plasma predicts outcome after seroconversion. Ann Intern Med. $1995 ; 122: 573-9$

20. Mellors JW, Munoz A, Giorgi JV, Margolick JB, Tassoni CJ, Gupta P, et al. Plasma vira load and CD4+ lymphocytes as prognostic markers of HIV-1 infection. Ann Intern Med. 1997;126:946-54.

21. Perelson AS, Neumann AU, Markowitz M, Leonard JM, Ho DD. HIV-1 dynamics in vivo: virion clearance rate, infected cell life-span, and viral generation time. Science. 1996;271:1582-86

22. Piatak M Jr, Saag MS, Yang LC, Clark SJ, Kappes JC, Luk KC, et al. High levels of HIV1in plasma during all stages of infection determined by competitive PCR. Science. 1993;259:1749-54

23. Robertson K, Fiscus S, Kapoor C, Robertson W, Schneider G, Shepard R, et al. CSF, plasma viral load and HIV associated dementia. J Neurovirol. 1998;4:90-4.

24. Schrager LK, D' Sousa MP. Cellular and anatomical reservoirs of HIV-1 in patients receiving potent antiretroviral combination therapy. JAMA. 1998;280:67-71.

25. Smith DM, Zárate S, Shao H, Pillai SK, Letendre SL, Wong JK, et al. Pleocytosis is associated with disruption of HIV compartmentalization between blood and cerebral spinal fluid viral populations. Virology, 2009;385:204-8.

Received: 6 January 2010

Accepted: 18 May 2011 